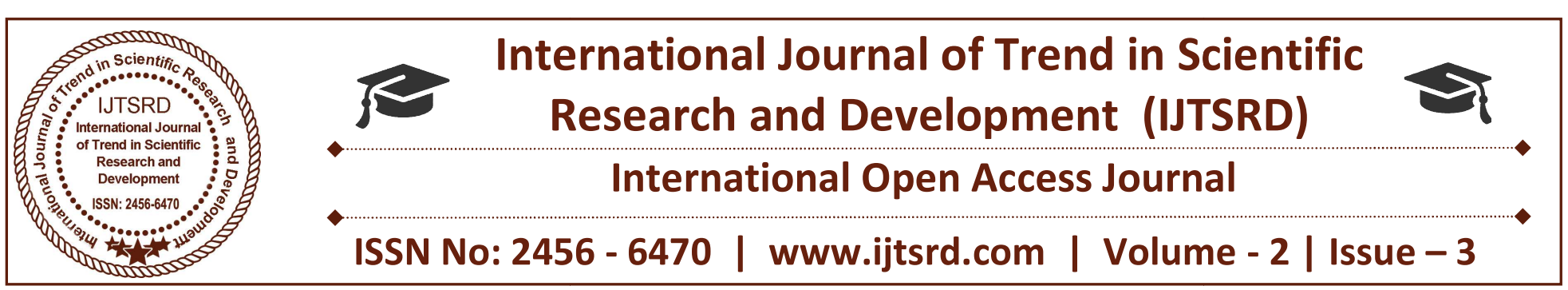

\title{
Administering Developmental Projects in Africa: An Analysis of Infrastructure Model under the Forum on China-Africa Cooperation (FOCAC)
}

\author{
Sheriff Ghali Ibrahim, Zainab Gimba, Olamiriki Oluwaseun
}

Department of Public Administration, University of Maiduguri, Nigeria

Department of Political Science And International Relations, University of Abuja, Nigeria

\section{ABSTRACT}

The paper delves into the activities and progress of the forum on China-Africa cooperation, which serves as the vein through which cooperation on the basis of mutual benefits flourishes. From the library instrument used, findings show that the two sides explore mutual cooperation and benefits. It also concludes that, china has been a major financier of infrastructural development in virtually all regions of Africa; therefore, Africa should continue to work with China. The paper recommends dealing with language barrier as an obstacle to the cooperation.

\section{INTRODUCTION}

China's relations with Africa have been at the centre of a debate for some time now, as they are seen as emerging competitors of the West in the region. China's involvement with these states as opined by some scholars is based on reciprocity and treating China as an equal partner. It is said that Chinese foreign policy has always been guided by the Confuciunist principle of doing unto others as you would have them do unto you. It is in light of this that Chinese relations with African states have been said to be different from that of the West which most of the time have conditionalities attached. China's relations with Africa are driven by four factors; resource scarcity, the need for new markets and investment opportunities, symbolic diplomacy, developmental assistance and cooperation and forging strategic partnerships (Udeala, 2010:68). With China being the fastest growing economy in the world, it needs energy and also markets for her productions and sees Africa as a viable place. In the same vein, Africa needs infrastructures and as such both see the need for the relationship.

Against this background, the forum on China- Africa cooperation (FOCAC) was established in 2000 between China and African states. The FOCAC was designed to boost economic and social development for Africa and it consisted of three high profile ministerial meetings between 2000 and 2006. FOCAC served as a mechanism for multilateral dialogue to indicate China's lasting presence in Africa. China's new form of regionalization in form of multilateralism like the FOCAC is different from that of the West which has dominated the international system for years. China's rhetorics has always been a practice of engaging other states in the practice of doing together, that is they do as China does, as against the Western rhetoric and conditionality of 'do as I say, not as I do' (Kavalski, 2009:5). China's activities in Africa through the FOCAC have shown that she is ready to mingle and engage in respectful interactions with the states in the region. China's support has been mainly providing iconic infrastructural projects and constructing edifices that would benefit the African people for a very long time. Lack of infrastructures are known to be one major problem of the African state as despite their enormous natural resources, the infrastructures are lacking and as such this hampers development.

Through the multilateral FOCAC platform, China then engages in bilateral relationships with each state. 
African states like Tanzania, Botswana, Ethiopia, Malawi and even Nigeria have all benefitted from this platform. This study therefore seeks to identify and give an overview of Chinese infrastructural development in Africa through the FOCAC platform and how these projects have aided development in the region (Udeala, 2010:68).

\section{THEORETICAL FRAMEWORK}

In the quest for a comprehensive theory to explain China- Africa relations under the FOCAC platform, the inter-governmentalist theory would be employed. Inter-governmentalism as a theory of regional integration was proposed by Stanley Hoffman and refined by Andrew Moravcsik. This theory sees states and their national governments as the primary actors in the integration process. This is to say that the government control the level and speed of integration. This theory posits that integration is determined by state's interest, and as such viewed as strengthening the nation state since it is carried out according to its rules. Under this theory, supranational institutions are denied any significant independent entrepreneurship and are subject to amendment / by member governments (Bergamann and Niemann, 2013:7).

According to Moravcsik, the preferences of a state arise in the context provided by the domestic politics of the state. In this regard, the main reason why states come together and integrate lies in their interest and also bargaining power. This is to say that any greater involvement by states at the supranational level actually results from a direct decision by governments who make the decisions based on domestic agenda (Bergamann and Niemann, 2013:7). Even though other actors like interest groups can influence their government's policies domestically, they do not have the power to cause their governments to integrate as the states are independent decision makers because they are legitimate. In essence, inter-governmentalism necessarily has to do with cooperation between and amongst governments of a state or states. Intergovernmentalism could take the form of bilateral, multilateral or even tripartite relations. It is a political or economic relationship that exists between states.

The relevance of this theory to China- African relations under the Forum of China- African cooperation (FOCAC) is based on the fact that the decision to come together and create this platform was solely based on the decisions of states involved. China, as a state is not just involved in sheer benevolence, even though we say there are no strings attached in Chinese infrastructural development in Africa, China sees the need to engage in this relations for different reasons which include but not limited to the need for a large market, the need for energy. Africa on the other hand views the platform as an opportunity to develop through infrastructures, aid and loans for its economy(Bergamann and Niemann, 2013:7).

Also, in the relations between China and Africa, the states involved get to control how involved they want to be and the speed they want the integration process to take. In fact, they also get to control the terms of integration as it suits them. In Nigeria for instance, during the Obasanjo regime, the government saw that the country lacked infrastructures to boost development and as such employed the oil for infrastructure deal with the Chinese, a few years after, the new regime of Yar'adua changed the game and scrapped the previous agreement. This is to say that domestic realities and governments of each States have the power to dictate its terms of relations as long as it can bargain it out with the other(Bergamann and Niemann, 2013:7).

In all, just like inter-governmentalism posits that these relations could take different forms, either bilateral, multilateral or tripartite, Chinese relations with Africa through the FOCAC which is multilateral in fact, still has a bilateral tune to it, as China through the platform also operates with the countries involved on a bilateral basis, this means that infrastructural projects and many more are carried out bilaterally.

\section{LITERATURE REVIEW}

This aspect of the study seeks to review a number of related literatures which would enhance our understanding of the topic. Many academic literatures and works have explored infrastructural developments between Nigeria and China under the FOCAC. Enuka (2011) opines that the experience of FOCAC over the last nine years has proven to be an important platform and dialogue mechanism for strengthening ChinaAfrica cooperation and solidarity, and safeguarding common interests. With both sides observing that this relationship can only be a win- win situation, the future of China- Africa relations is definitely moving into an era of rapid development. Enuka's claim in fact buttresses the position of the then Chinese President, Hu Jintao who at the opening ceremony of the FOCAC Beijing summit claimed that the platform 
was to enhance mutual trust and cooperation between both countries as against the idea that China was in Africa to take advantage of the African states, as it should be stated that way before the FOCAC platform was established, China was already in the business of infrastructural development in the region. Avery good example of this was the Tazara railway in Tanzania (Enuka, 2011').

Along this line, Shelton and Paruk (2008) further assert that the FOCAC process provides a unique diplomatic mechanism to promote dialogue between Nigeria and China, while at the same time facilitate the development of a common political and economic agenda which will advance constructive South- South cooperation for mutual benefit. They further opine that FOCAC deliberations have brought African and Chinese leaders closer together and crafted a shared vision for policy coordination, expanded commercial interaction and common prosperity.

Foster, Butterfield, Chen and Pushak (2008) posit that Chinese finance often goes to large scale infrastructural projects, with a particular focus on hydropower generation and railways. More than 35 African countries are engaging with China on infrastructure finance deals, with the biggest recipients being Nigeria, Angola, Sudan and Ethiopia. Chinese finance is on a scale large enough to make a material contribution towards meeting Africa' vast infrastructure needs. They therefore conclude that this offers an important development opportunity for the region. Of a truth, Foster and co's claim still hold water today as large infrastructural projects in African countries continue to be carried out by China. The recent railway completion in Nigeria and Tanzania also attests to this.

In the same vein, Shelton and Paruk (2008) further claim that Chinese assistance to Africa has essentially focused on four key areas, that is China has started to fund infrastructure projects, an area which the World Bank and international donors stopped funding in the 1990s. In view of the fact that sustainable development is impossible without infrastructure, China's activities are highly welcomed.

\section{FOCAC: A Brief Background}

The lynchpin of Sino- African relations is the Forum on China- Africa cooperation (FOCAC) initiated at the Ministerial Conference in Beijing in 2000. The forum, driven by a joint Ministerial Conference held every three years since 2000, aims at fostering solidarity and cooperation based on equality, consulation, consensus, friendship, partnership and mutual benefit (Hellstrom, 2009). The outcomes of the conference in Beijing included the Beijing declaration and the Program for China- Africa cooperation in Economic and Social development which laid the basis for the strategic partnership in the new millennium. Scholars have argued that FOCAC should be seen as a continuum of the spirit of the Bandung Conference of 1955 in Indonesia where developing countries came together under the SouthSouth cooperation to foster overall development in their respective states. As stated earlier, the first FOCAC held in 2000 in Beijing and focused on two major areas which included how to promote an establish a just and equitable new international economic order and also strengthen China- Africa on economic and social development. Also, there were follow- up processes after the meeting to ensure that all that was deliberated upon were carried out, with meetings to assess their progress held in Lusaka in 2001 and in Addis Ababa in 2002 (Enuka, 2011: 223).

The second Forum on China- Africa cooperation was held in Addis Ababa, Ethiopia in December, 2003 and its main aim was to review the implementation of the policies adopted in the first FOCAC, and furthermore deepen cooperation in areas of infrastructure, investment and many others, as lack of infrastructure was seen as the major problem of African states. The second FOCAC led to the signing of many contracts between China and Africa as over 100 Chinese enterprises were present (Enuka, 2011:223).

The third Ministerial meeting of FOCAC together with the first Sino- African Heads of States Summit held in Beijing in November, 2006. The third FOCAC was launched by two significant development in 2006 which included the release of the White Paper on China's African policy and the then President of China, Hu Jintao's speech at the Nigerian congress in April. These set a new tune to China- Africa relations. FOCAC 2006 concluded a year that was dubbed by the Chinese as China's "Year of Africa" (Naidu, 2006: 41).

The fourth FOCAC which held in 2009 saw about 50 countries gathered in Egypt. The Chinese Prime Minister, Wen Jiabao declared eight new measures to strengthen Sino- African cooperation which include helping Africa to build up its financing capacity, construction of buildings, schools, hospitals amongst others (ChinaAfrica, 2009). 
FOCAC has proven to be an important platform for fostering China- Africa relations in virtually all aspects.

\section{FOCAC: An Overview of Infrastructural Development}

According to Shelton and Paruk (2008:4), China's commitment to develop Africa's infrastructure and further economic development is proof of China's intentions to assist Africa over the longer time rather than simply seek an exploitative relationship based on oil and mineral extraction. In fact, China's role on the continent has contributed to a significant improvement in infrastructure part from the fact that China is involved in construction in Africa, which is an area that has been neglected by the West since the 1990s. Unlike speculations from some angles that China has only come to exploit Africa of its natural resources and disappear later, the Chinese government in 2013, through a Chinese development firm, Zendai Property Limited announced it was building an $\$ 8$ billion city outside Johannesburg, called the Modderfontein New City which will become a hub for Chinese firms investing in African infrastructure which further gives credence to the fact that China has come to stay and develop Africa's infrastructure and so as to promote mutual benefits(Weller, 2016).

According to Rudolf (2016:35), the FOCAC in fact, share significant characteristics with the activities of China in some other South- South cooperation like the Shanghai cooperation (SCO) and the Association of South- East Asian Nations (ASEAN) as even under these platforms, China continues to place emphasis on the development of regional infrastructure and reshaping the current international relations order. Also, when it comes to infrastructural development of Africa, China has always been at the fore front even before the establishment of FOCAC. The construction of the Tanzania- Zambia Railway in 1976 attests to that fact, this is to say that the FOCAC was only created to strengthen the relations that had always existed.

China recognizes that lack of infrastructure is the major obstacle to Africa's development and that is why it has been a huge priority under FOCAC. The infrastructure Consortium for Africa puts Chinese investment in African infrastructure at roughly \$13.9 billion a year between 2011 and 2013, which makes China the largest source of financing for infrastructure in Africa. It is in this light that China and the African
Union signed a memorandum of understanding to jointly develop infrastructure to connect the continent's capitals through road, rail and air transport routes as part of Agenda 2063 (Rudolf, 2016:3). It should be noted that Chinese infrastructural projects in Africa continues to grow in leaps and bounds. Between 2000 and 2011, the Chinese backed more than 1,700 projects, from building to dams in 50 African countries at a cost of $\$ 75$ billion. In Nigeria, a new rail- line which connects the Federal Capital City of Abuja to the city of Kaduna further north was unveiled in July, 2016. The 187- kilometer standard gauge track has nine stations. According to SAIS, the China- Exim bank loaned $\$ 500$ million towards the railway which cost a total of $\$ 874$ million. In the same vein, China also saw to the construction of a railway which was opened in 2014 in Sudan. The Nile Train is said to be 782 kilometers long, extending from Port Sudan via Atbara to the capital city of Khartoum. Even though the rail- line currently ends near the Nile River in Khartoum, future lines are expected to connect the railway to neighbouring countries (CNN, 2017).

In 2015, a 1,344- kilometers railroad project spanning Angola was completed and put into operation. The Lobito- Luau railway boasts the fastest travelling speed in Angola and serves as a significant economic corridor in the country. The railway links the coastal city of Lobito in the west and Luau city that borders the Democratic Republic of Congo. It not only facilitates easier movement of goods and services, but invariably contributes to development in Angola (ChinaDaily, 2017).

To buttress the activities of China in Africa's infrastructural development, it spearheaded the construction of a railway in Kenya connecting Mombasa to Nairobi. The railway in Kenya is in fact a sub- project of a bigger project which is supposed to link Mombassa with other major East African cities such as Kampala in Uganda, and Juba in South Sudan. The latest of Chinese infrastructural projects in terms of railways to be inaugurated is a 756- kilometer railway in Ethiopia which links the country's capital city to Djibouti. This new rail- line gives landlocked Ethiopia access to the Red Sea port in Djibouti (CNN, 2017).

Chinese assistance in terms of infrastructural development in Africa goes a long way to boost trade and investments amongst the states in the region 
which in turn leads to economic development, and also speeds up industrialization process.

Asides the Tanzania- Zambia railway, the Kigamboni Bridge was also inaugurated in the commercial city of Dar es Salaam of Tanzania. The 680- meter- long bridge is the first of its kind in Eastern and Central Africa as it connects the Dar es Salaam business district with the Kigamboni Creek. Even though the bridge was funded by the Tanzanian government, it was built by the China Railway Construction Engineering Group and China Railway Major Bridge Group. The Chinese also saw to the construction of a $140 \mathrm{~km}$ road in Tsangano- Mwanza in Tanzania worth $\$ 169.4$ million (ChinaDaily, 2017). In the same Tanzania, a Chinese government construction firm currently oversees the construction of the Bagamoyo Port which will become Africa's largest port, capable of handling 20 million containers per year upon completion.

In East Africa, China is not just about building railways and facilitating trade. Instead, it launched the construction of a 50-megawatt PV power plant in Northeast Kenya's Garissa County in 2016 jointly with the Kenyan government. The project was financed by the Export- Import Bank of China which provided a concessional loan of $\$ 135$ million for the largest PV power plant in East Africa. According to the project's Chinese contractor, the plant, upon completion will generate more than 7,600 kilowatthours of power each year and reduce a yearly carbon dioxide emission of 64, 190 metric tons (ChinaDaily, 2017). Still on hydro- electric projects, China also signed a deal with the Mozambican government to build the Mphanda Nkuwa Dam and hydroelectric station project. The project would invariably provide 1,500 megwatts of power to the national electricity grid of Mozambique.

In Malawi, China has funded $\$ 1.7$ billion worth of infrastructural projects in the country. The deal includes a 300 megawatts coal- powered station at Kam'mwamba and the reconstruction of the Chileka International Airport (ChinaDaily, 2017).

In respect to all this, China has and continues to contribute to development in Africa. This is in respect of the fact that infrastructural development also contributes to economic growth.

For further understanding, below is a list of infrastructures carried out by China in some African countries.

\begin{tabular}{|c|c|c|c|}
\hline Year & Country & Infrastructure & Amount \\
\hline 2000 & $\Delta E$ & Telecommunications & $\$ 966$ million \\
\hline 2001 & Sudan $1 \mathrm{CC}$ & Power 6170 & $\$ 110$ million \\
\hline 2002 & Morocco & Dam & \$603 million \\
\hline 2003 & Congo $\left(\theta_{2}, \theta_{0}\right.$ & Dam Infrastructure & $\$ 280$ million \\
\hline 2003 & Djibouti & Telecommunications & $\$ 12$ million \\
\hline 2003 & Ethiopia & Dam & \$224 million \\
\hline 2003 & Zambia & Dam & $\$ 600$ million \\
\hline 2004 & Angola & Transport Infrastructure & $\$ 2$ billion \\
\hline 2004 & Botswana & Housing & $\$ 24.13$ million \\
\hline 2004 & Tunisia & Telecommunications & \$16.89 million \\
\hline 2005 & Angola & Energy & $\$ 1-3$ billion \\
\hline 2005 & Botswana & Roads & \$18.29 million \\
\hline 2005 & Egypt & Textiles & $\$ 15.85$ million \\
\hline $2005 / 6$ & Mozambique & Dam & $\$ 300$ million \\
\hline $2005 / 6$ & Mozambique & Dam/ Plant infra. & $\$ 2.3$ billion \\
\hline
\end{tabular}


International Journal of Trend in Scientific Research and Development (IJTSRD) ISSN: 2456-6470

\begin{tabular}{|c|c|c|c|}
\hline 2005 & Namibia & Transport & \$19 million \\
\hline 2006 & Eritrea & Telecommunications & \$20.80 million \\
\hline 2006 & Kenya & Electricity & \$20.17 million \\
\hline 2006 & Kenya & Telecommunications & \$29.94 million \\
\hline 2006 & Nigeria & Dam/ power infra. & $\$ 2.5$ billion \\
\hline 2006 & Tunisia & Telecommunications & $\$ 6.26$ million \\
\hline 2007 & DRC & Mining Infra. & $\$ 8.5$ billion \\
\hline 2007 & Eritrea & Mining & $\$ 60$ million \\
\hline 2007 & Ethiopia & Hydropower/ Irrigation, etc & \$208 million \\
\hline 2007 & Ghana & Dam & $\$ 292$ million \\
\hline 2007 & Ghana & Power & $\$ 137.2$ million \\
\hline 2007 & Zambia & Plant infra. & $\$ 206.55$ million \\
\hline 2008 & & Glass Facto & $\begin{array}{l}\text { Part of a } \$ 90 \text { million } \\
\text { contribution to projects } \\
\text { in three countries }\end{array}$ \\
\hline 2008 & Zimbabw & Mining & $\begin{array}{l}\text { Part of a } \$ 90 \text { million } \\
\text { contribution to projects } \\
\text { in three countries }\end{array}$ \\
\hline
\end{tabular}

Source: Centre for Chinese studies, Stellenbosch University. H.Edinger, How China delivers development assistance to Africa.

\section{FINDINGS AND DISCUSSION}

Having examined China- Africa relations under FOCAC, it has been discovered that the strategic partnership has been of mutual benefit to both states. China, on one hand gets a great advantage of African market as Africa is the second most populous continent while Africa continues to enjoy infrastructural development from China. This work has been able to show China's presence in over 50 African states in terms of constructions of dams, hydro- electric projects, railways and even roads. In this light, the question of why Chinese infrastructural development has not generated improvements in the life of the common man in Africa is asked. Ordinarily, infrastructural development is supposed to invariably contribute to the standard of the people and make life easier for them, and as such provide a conducive environment for economic development. With all of Chinese infrastructural projects in Africa, some scholars have even opined that there is a lopsided relationship in China's favour, that there is a case of unequal exchange. Could this unequal exchange be China's fault? The problem has always been from African leaders who do not necessarily have a genuine policy towards China. China in fact encourages them to take advantage of the relations because judging from all facts, China through multilateral platforms like the FOCAC and those in Asia continue to emphasize the need for the developing world to be economically empowered so as to change the international relations order.

This sums up the fact that China is genuinely interested in the affairs of Africa. Taking a look at infrastructural projects in some African countries, some projects worth billions of dollars were singlehandedly undertaken by the Chinese government. Worthy of note is the fact that China does not even attach hidden or open conditionalities which could damage growth in African economies. In essence, China's activities in Africa are just like a blank cheque which the African states get to fill in themselves.

In some quarters, there has been arguments that Chinese projects are inferior and do not stand the test of time. An example of this was the said shoddy execution of Nigeria's first telecommunication satellite, the Nig- ComSat- 1in 2006, which was 
packed up and powered down because the solar power function failed to work amongst other cases. Asides the fact that China is also developing even though at a rapid pace, there are bound to be issues of this nature which should be rectified as time goes on, but not enough to cause a strain in the relationship as the advantages far outweigh the disadvantages.

\section{CONCLUSION}

This study has diligently examined infrastructural development under the Forum on China- Africa cooperation. It was observed that China has been the major contributor and financer of infrastructure in Africa. Chinese presence has been felt in virtually all regions in the continent; North, East, West and South Africa. The FOCAC has effectively served as a platform for interaction and dialogue for African states with China. It can be said to be living up to expectations as both Africa and China are happy with the level at which they have gone. China continues to see infrastructure as necessary for development in the region and as such goes all out to help these states.

This work proposes that Sino-Africa relations have been more of a win- win situation as opposed to a lopsided relationship that is being speculated in some quarters. It is true that the balance of trade is to China's advantage, but this does not erase the fact that Africa benefits in no small way from the relations unlike her relations with the West.

This study hereby concludes that China can only be the best partner for the African continent and as such both sides should find better ways to get maximum advantage from the FOCAC.

\section{RECOMMENDATIONS}

After a careful study of the Forum on China- Africa cooperation, with emphasis on infrastructural development, the following recommendations are hereby made:

African states and policy makers should set up policies that will give maximum advantage in the relations.

Cultural and language barriers which affect free flow of interactions at the FOCAC should be looked into.

Africans (Technicians) should also be a part of infrastructural projects by China so as to be familiar with how it works.

\section{REFERENCES}

1. Bergamann, J. and Niemann, A. (2013), Theories of European Integration and their contribution to the study of European Foreign Policy. A paper prepared for the $8^{\text {th }}$ Pan- European conference on International Relations, Warsaw 2013.

2. ChinaDaily (2017), Major China- Africa Infrastructural Cooperation Projects

3. Enuka, C. (2011), The Forum on China- Africa Cooperation (FOCAC): A Framework for China's re-engagement with Afria in the $21^{\text {st }}$ century. Institute for International Studies Journal, vol. 6, no. 2 .

4. Foster, V.,Butterfield, W., Chen, C., and Pushak, N. (2008), Building Bridges: China's growing role as Infrastructure Financier for Sub- Saharan Africa. World Bank: Public- Private Infrastructure Advisory Facility.

5. Hellstrom, J. (2009), China's Emerging Role in Africa. A strategic overview. Sweden:FOI.

6. http://m.chinadaily.com.cn/en/2017-3/26/content28682186.htm

7. Kavalski, E. (2009), China and the Global Politics of Regionalisation. England: Ashgate Publishing Ltd.

8. Naidu, S. (2006), China-African Relations in the $21^{\text {st }}$ century: A win- win relationship.

9. "Rudolf, P. (2016), China's African Infrastructural Projects, A tool in reshaping global norms. South African Institute of International Affairs, policy insight 35.

10. Shelton, G. and Paruk, F. (2008), The Forum on China- Africa Cooperation: A strategic opportunity. Institute for Security Studies, Monograph 156.

11. Sophie, M. (2017), All aboard: The Chinese funded railways linking East Africa (www.cnn.com) Jan. 17, 2017.

12. Udeala, S. (2010), Nigeria- China Economic Relations under the South- South cooperation. African Journal of International Affairs, volume 13 , numbers $1 \& 2$.

13. Weller, C. (2016). 11 Giant Infrastructural Projects that are reshaping Africa. Business Insider, Dec. 18, 2016. 